\title{
PENERAPAN DATA MINING UNTUK KLASIFIKASI PENYAKIT HEPATOCELLULAR CARCINOMA MENGGUNAKAN ALGORITMA NAÏVE BAYES
}

\author{
Bambang Tri Rahmat Doni ${ }^{1}$, Sari Susanti ${ }^{2}$, Ade Mubarok $^{3}$ \\ 1 Universitas Adhirajasa Reswara Sanjaya \\ Email: geniuses17@gmail.com \\ ${ }^{2}$ Universitas Adhirajasa Reswara Sanjaya \\ Email: sarisusanti@ars.ac.id \\ ${ }^{3}$ Universitas Adhirajasa Reswara Sanjaya \\ Email: adem@ars.ac.id
}

\begin{abstract}
Abstrak
Hepatocellular Carcinoma merupakan tumor ganas hati primer yang berasal dari hepatosit. Dalam dasawarsa terakhir terjadi perkembangan yang cukup berarti menyangkut penyakit Hepatocellular Carcinoma. Penelitian ini bertujuan untuk mengklasifikasikan tingkat kemungkinan hidup pasien yang telah di diagnosis menderita penyakit Hepatocellular Carcinoma dengan menggunakan penerapan metode data mining serta melakukan pengukuran terhadap performa algoritma Naïve Bayes dengan mengacu kepada Confusion Matrix dan Kurva ROC. Data sekunder yang digunakan merupakan data publik yang bernama HCC Survival Data Set yang dirilis pada tahun 2017 dan diperoleh dari website UCI Machine Learning Repository. Algortima Naïve Bayes merupakan salah satu algoritma yang terdapat dalam metode data mining yang menerapkan Teori Keputusan Bayes pada teknik klasifikasi dengan menggunakan cara pendekatan statistik yang bersifat fundamental dalam pengenalan pola. Teknik validasi yang digunakan menggunakan teknik 10-Fold Cross-Validation dengan rasio pembagian data sebesar 90:10. Perangkat lunak yang digunakan adalah RapidMiner Studio v9.5. Hasil penelitian menunjukkan bahwa hasil performa algoritma Naïve Bayes yang diukur menggunakan Confussion Matrix dengan nilai yang dihasilkan berupa nilai Akurasi sebesar $70,30 \%$, Presisi sebesar $73,53 \%$ dan Recall sebesar $77,32 \%$ serta hasil performa yang diukur menggunakan Kurva ROC (Receiver Operating Characteristic) dengan nilai yang dihasilkan berupa nilai AUC sebesar 0.783 yang termasuk dalam kategori Fair Classification atau kategori Klasifikasi Cukup.
\end{abstract}

Kata Kunci: Penyakit Hepatocelullar Carcinoma, HCC Survival Data Set, Naïve Bayes, Klasifikasi.

\begin{abstract}
Hepatocellular Carcinoma is a primary liver malignant tumor derived from hepatocytes. In the last decade there is considerable development means concerning the disease of Hepatocellular Carcinoma's. This research aims to classify the possible life levels of patients who have been diagnosed with Hepatocellular Carcinoma by using the application of data mining methods and performing measurements of the Naïve Bayes algorithm performance's with reference to the Confusion Matrix and the ROC Curve. The secondary data used is a public data called HCC Survival Data Set which was released in 2017 and obtained from the UCI Machine Learning Repository website. Naïve Bayes algorithm is one of the algorithms contained in data mining methods that apply Bayes decision theory to the classification technique by using a statistical approach that is fundamental in the introduction of patterns. The validation technique is used using the 10-Fold Cross-Validation technique with a data sharing ratio of 90:10. The software used is RapidMiner Studio v 9.5. The results showed that Nä̈ve Bayes algorithm performance's was measured using Confussion Matrix with the resulting value of accuracy value of $70.30 \%$,
\end{abstract}


precision at $73.53 \%$ and Recall of $77.32 \%$ and the performance results Measured using the Receiver Operating Characteristic with the resulting value in the form of a AUC of 0783 which belongs to the category of Fair Classification or sufficient classification category.

Keywords: Hepatocelullar Carcinoma Disease, HCC Survival Data Set, Naïve Bayes, Classification.

\section{Pendahuluan}

Kanker merupakan suatu penyakit yang disebabkan oleh pertumbuhan sel-sel jaringan tubuh yang tidak normal. Sel-sel kanker akan berkembang dengan cepat, tidak terkendali, dan akan terus membelah diri, selanjutnya menyusup ke jaringan di sekitarnya (invasive) dan terus menyebar melalui jaringan ikat, darah, dan menyerang organ-organ penting serta saraf tulang belakang. Dalam keadaan normal, sel hanya akan membelah diri jika ada penggantian selsel yang telah mati dan rusak. Sebaliknya, sel kanker akan membelah terus meskipun tubuh tidak memerlukannya, sehingga akan terjadi penumpukan sel baru. Penumpukan sel tersebut mendesak dan merusak jaringan normal, sehingga mengganggu organ yang ditempatinya (Sugiarti, 2015).

Salah satu jenis kanker yang patut diwaspadai adalah kanker hati atau dalam bahasa medis biasa disebut juga dengan Hepatocellular Carcinoma (HCC). Kanker hati merupakan salah satu jenis kanker yang paling sering ditemui oleh masyarakat (Yulianto, Kuzairi, \& Hasanah, 2016), hal ini terbukti dari data yang didapat dari data Globocan yang menyebutkan bahwa di tahun 2018 terdapat 18,1 juta kasus baru dengan angka kematian sebesar 9,6 juta kematian, dimana 1 dari 5 laki-laki dan 1 dari 6 perempuan di dunia mengalami kejadian kanker. Data tersebut juga menyatakan 1 dari 8 laki-laki dan 1 dari 11 perempuan, meninggal karena kanker (Kemenkes, 2019).

Penderita dinyatakan mengidap kanker Hepatocellular Carcinoma (HCC) setelah didiagnosa memiliki kanker tahap lanjut, sehingga diperlukan diagnosis lebih awal untuk mendeteksi kanker Hepatocellular Carcinoma (HCC) agar pasien dapat memiliki kesempatan untuk selamat dari penyakit tersebut (Nugraha, Shidiq, \& Rahayu, 2019).

Data mining merupakan kegiatan mengekstrak informasi atau pengetahuan (knowledge) penting dari suatu set data berukuran besar yang meliputi pengumpulan, pemakain data historis untuk menentukan pola keteraturan, pola hubungan dengan menggunakan teknik tertentu (Santosa \&
Umam, 2018). Dalam dunia kesehatan penggunaan metode data mining telah banyak membantu dunia kesehatan dalam membuat prediksi mengenai masalah kesehatan yang dihadapi (Amalia, 2018). Terdapat beberapa teknik pada data mining yang dapat digunakan untuk mengelola hasil diagnosis pada dunia medis, salah satunya adalah dengan menggunakan teknik klasifikasi. Teknik klasifikasi pada data mining juga pernah digunakan pada penelitian (Susanti, 2019), (Ramdhani et al., 2018) \& (Ramdhani, 2015).

Salah satu metode yang sering digunakan untuk menerapkan teknik klasifikasi adalah metode Naïve Bayes. Naïve Bayes merupakan sebuah metode untuk teknik pengklasifikasian dengan konsep probabilistik sederhana yang menghitung sekumpulan probabilitas dengan menjumlahkan frekuensi dan kombinasi nilai dari dataset yang diberikan. Adapun keuntungan dalam penggunaan metode Naïve Bayes sebagai metode untuk menerapkan teknik klasifikasi yaitu metode ini hanya membutuhkan jumlah data pelatihan (Training Data) yang kecil untuk menentukan estimasi paremeter yang diperlukan dalam proses pengklasifikasian (Saleh, 2015).

\section{Metode Penelitian}

Pada penelitian ini akan menggunakan metodologi penelitian secara keseluruhan yang didasarkan pada konsep Knowledge Discovery in Database (KDD). Berikut adalah tahapan yang dilakukan dalam penelitian ini : 


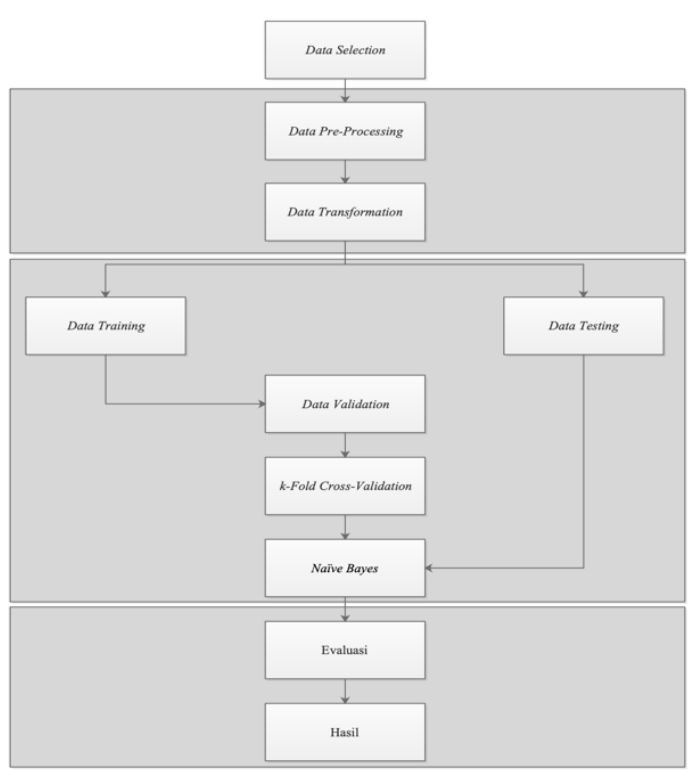

Gambar 1. Desain Penelitian

Sumber: Penelitian (2019)

\section{Data Selection}

Pada tahapan awal ini, penulis mengambil data sekunder yang telah disediakan oleh website $\mathrm{UCl}$ Machine Learning Repository dengan judul HCC Survival Data Set yang dipublikasikan pada tahun 2017 dengan berisikan data pasien sebanyak 165 orang dan setiap data tersebut memiliki atribut atau fitur data sebanyak 49 atribut/fitur dengan jumlah pasien yang terdiagnosis 0 atau Dies (Meninggal) sebanyak 63 pasien dan jumlah pasien yang terdiagnosis 1 atau Lives (Selamat) sebanyak 102 pasien.

\section{Data Pre-Processing/Cleaning}

Pada tahap ini, penulis melakukan pre-processing terhadap data sekunder yang telah didapatkan sebelumnya dengan tujuan agar dapat menyesuaikan dan memperbaiki isi dari data sekunder tersebut sesuai dengan deskripsi yang diberikan oleh donatur data sekunder tersebut. Data pre-processing dalam penelitian ini dilakukan dengan cara memperbaiki data dan mengisi missing value yang ada dengan cara menggantinya menjadi nilai rata-rata dari nilai atribut/fitur keseluruhan dari masing-masing jenis atribut/fitur yang dilakukan untuk setiap masing-masing jenis atribut/fitur yang masih memiliki missing value. Pengisian missing value juga dilakukan untuk jenis atribut/fitur yang memiliki data bersifat nominal maupun ordinal dengan cara membulatkan nilai dari rata-rata untuk seluruh data pada tiap masing-masing jenis atribut/fitur dengan memberi nilai 1 jika nilai rata-rata dari jumlah data pada atribut/fitur tersebut bernilai $>0.5$ dan memberikan nilai 0 jika nilai rata-rata dari jumlah data pada atribut/fitur tersebut bernilai $<=0.5$. Untuk jenis atribut/fitur yang memiliki data bersifat numerik maupun rasio dilakukan pengisian missing value dengan cara mengisi missing value tersebut dengan nilai rata-rata dari jumlah data pada atribut/fitur tersebut dan hanya nilai dibelakang koma yang akan dibulatkan menjadi nilai terdekat dari koma.

\section{Data Transformation}

Pada tahap ini, penulis melakukan proses transformasi data dengan mengubah tipe data yang mengandung nilai continuous menjadi tipe data yang mengandung nilai kategorikal. Hal ini dilakukan agar kinerja dari algoritma Naïve Bayes yang digunakan bisa lebih optimal dalam mengklasifikasikan suatu kasus. Pada HCC Survival Data Set yang digunakan pada penelitian ini, terdapat jenis nilai atribut/fitur campuran antara jenis nilai atribut/fitur yang bersifat nominal maupun ordinal dengan jenis nilai atribut/fitur yang bersifat numerik maupun rasio. Proses transformasi data yang digunakan pada penelitian ini adalah metode Discretization, dimana dalam tahap ini nilai-nilai baku dari atribut/fitur dengan jenis numerik (misalnya; Age at diagnosis) akan diganti dan dikelompokkan dengan suatu rentang nilai yang telah ditentukan (misalnya; 20-25 tahun digolongkan menjadi Remaja Akhir). Proses ini dilakukan untuk mengubah semua jenis nilai atribut/fitur yang bersifat nominal maupun ordinal dan numerik maupun rasio menjadi jenis nilai atribut/fitur dengan jenis nilai interval maupun kategorikal. Berikut ini adalah transformasi untuk 49 jenis atribut/fitur yang dilakukan proses Discretization.

Tabel 1. Hasil Transformasi Atribut/Fitur Menggunakan Discretization

\begin{tabular}{|c|c|c|}
\hline No. & Atribut/Fitur & Nilai \\
\hline 1. & Gender & $\begin{array}{c}1=\text { Male } \\
0=\text { Female }\end{array}$ \\
\hline 2. & Symptoms & $\begin{array}{c}1=\text { Yes } \\
0=\text { No }\end{array}$ \\
& & $1=$ Yes \\
& Alcohol No \\
\hline 3. & Hepatitis B & $1=$ Yes \\
& Surface Antigen & $1=$ Yes \\
\hline 4. & Hepatitis B & $0=$ No \\
& Antigen & $1=$ Yes \\
& Hepatitis B Core & No \\
\hline 5. & Antibody & \\
\hline 6. &
\end{tabular}




\begin{tabular}{|c|c|c|}
\hline 7. & $\begin{array}{l}\text { Hepatitis C Virus } \\
\text { Antibody }\end{array}$ & $\begin{aligned} 1 & =\text { Yes } \\
0 & =\text { No }\end{aligned}$ \\
\hline 8. & Cirrhosis & $\begin{array}{l}1=\text { Yes } \\
0=\text { No }\end{array}$ \\
\hline 9. & $\begin{array}{l}\text { Endemic } \\
\text { Countries }\end{array}$ & $\begin{array}{l}1=\text { Yes } \\
0=\text { No }\end{array}$ \\
\hline 10. & Smoking & $\begin{array}{l}1=\text { Yes } \\
0=\text { No }\end{array}$ \\
\hline 11. & Diabetes & $\begin{aligned} 1 & =\text { Yes } \\
0 & =\text { No }\end{aligned}$ \\
\hline 12. & Obesity & $\begin{array}{l}1=\text { Yes } \\
0=\text { No }\end{array}$ \\
\hline 13. & Hemochromatosis & $\begin{array}{l}1=\text { Yes } \\
0=\text { No }\end{array}$ \\
\hline 14. & $\begin{array}{c}\text { Arterial } \\
\text { Hypertension }\end{array}$ & $\begin{array}{l}1=\text { Yes } \\
0=\text { No }\end{array}$ \\
\hline 15. & $\begin{array}{l}\text { Chronic Renal } \\
\text { Insufficiency }\end{array}$ & $\begin{array}{l}1=\text { Yes } \\
0=\text { No }\end{array}$ \\
\hline 16. & $\begin{array}{c}\text { Human } \\
\text { Immunodeficiency } \\
\text { Virus }\end{array}$ & $\begin{array}{l}1=\text { Yes } \\
0=\text { No }\end{array}$ \\
\hline 17. & $\begin{array}{c}\text { Nonalcoholic } \\
\text { Steatohepatitis }\end{array}$ & $\begin{aligned} 1 & =\mathrm{Yes} \\
0 & =\mathrm{No}\end{aligned}$ \\
\hline 18. & $\begin{array}{l}\text { Esophageal } \\
\text { Varices }\end{array}$ & $\begin{array}{l}1=\text { Yes } \\
0=\text { No }\end{array}$ \\
\hline 19. & Splenomegaly & $\begin{array}{l}1=\text { Yes } \\
0=\text { No }\end{array}$ \\
\hline 20. & $\begin{array}{c}\text { Portal } \\
\text { Hypertension }\end{array}$ & $\begin{array}{l}1=\text { Yes } \\
0=\text { No }\end{array}$ \\
\hline 21. & $\begin{array}{l}\text { Portal Vein } \\
\text { Thrombosis }\end{array}$ & $\begin{aligned} 1 & =\text { Yes } \\
0 & =\text { No }\end{aligned}$ \\
\hline 22. & Liver Metastasis & $\begin{array}{l}1=\text { Yes } \\
0=\text { No }\end{array}$ \\
\hline 23. & $\begin{array}{l}\text { Radiological } \\
\text { Hallmark }\end{array}$ & $\begin{array}{l}1=\text { Yes } \\
0=\text { No }\end{array}$ \\
\hline 24. & Age at diagnosis & $\begin{array}{c}20-25=\text { Remaja Akhir } \\
26-35=\text { Dewasa Awal } \\
36-45=\text { Dewasa Akhir } \\
46-55=\text { Lansia Awal } \\
56-65=\text { Lansia Akhir } \\
66-95 \text { = Manula }\end{array}$ \\
\hline 25. & $\begin{array}{c}\text { Grams of Alcohol } \\
\text { per day }\end{array}$ & $\begin{array}{c}0-166,7=\text { Low } \\
166,8-333,4=\text { Medium } \\
333,5-500=\text { High }\end{array}$ \\
\hline 26. & $\begin{array}{c}\text { Packs of cigarets } \\
\text { per year }\end{array}$ & $\begin{array}{c}0-170=\text { Low } \\
171-340=\text { Medium } \\
341-510=\text { High }\end{array}$ \\
\hline 27. & $\begin{array}{l}\text { Performance } \\
\text { Status }\end{array}$ & $\begin{array}{c}0=\text { Active } \\
1=\text { Restricted } \\
2=\text { Ambulatory } \\
3=\text { Selfcare } \\
4=\text { Disabled } \\
5=\text { Dead }\end{array}$ \\
\hline 28. & $\begin{array}{l}\text { Encephalopathy } \\
\text { degree }\end{array}$ & $\begin{array}{c}1 \text { = None } \\
2=\text { Grade I/II } \\
3=\text { Grade III/IV }\end{array}$ \\
\hline 29. & Ascites degree & $\begin{array}{c}1=\text { None } \\
2=\text { Mild } \\
3=\text { Moderate to } \\
\text { Severe }\end{array}$ \\
\hline 30. & $\begin{array}{c}\text { International } \\
\text { Normalised Ratio }\end{array}$ & $\begin{aligned} 0-1,67 & =\text { Low } \\
1,68-3,34 & =\text { Medium } \\
3,35-5 & =\text { High }\end{aligned}$ \\
\hline 31. & $\begin{array}{l}\text { Alpha-Fetoprotein } \\
\text { (ng/mL) }\end{array}$ & $\begin{array}{c}0-603448,67=\text { Low } \\
603448,68- \\
1206897,34=\text { Medium } \\
1206897,35-1810346 \\
=\text { High }\end{array}$ \\
\hline 32. & $\begin{array}{l}\text { Haemoglobin } \\
(\mathrm{g} / \mathrm{dL})\end{array}$ & $\begin{array}{c}0-6,34=\text { Low } \\
6,35-12,68=\text { Medium }\end{array}$ \\
\hline
\end{tabular}

\begin{tabular}{|c|c|c|}
\hline & & $12,69-19=\mathrm{High}$ \\
\hline 33. & $\begin{array}{l}\text { Mean } \\
\text { Corpuscular } \\
\text { Volume (f1) }\end{array}$ & $\begin{array}{c}0-40=\text { Low } \\
41-80=\text { Medium } \\
81-120=\text { High }\end{array}$ \\
\hline 34. & Leukocytes (G/L) & $\begin{array}{c}0-4333,34=\text { Low } \\
4333,35-8666,68= \\
\text { Medium } \\
8666,69-13000=\text { High }\end{array}$ \\
\hline 35. & Platelets (G/L) & $\begin{array}{c}0-153000=\text { Low } \\
153001-306000= \\
\text { Medium } \\
306001-459000= \\
\text { High }\end{array}$ \\
\hline 36. & Albumin (mg/dL) & $\begin{array}{c}0-1,67=\text { Low } \\
1,68-3,34=\text { Medium } \\
3,35-5=\text { High }\end{array}$ \\
\hline 37. & $\begin{array}{l}\text { Total Bilirubin } \\
(\mathrm{mg} / \mathrm{dL})\end{array}$ & $\begin{aligned} 0-13,67 & =\text { Low } \\
13,68-27,34 & =\text { Medium } \\
27,35-41 & =\text { High }\end{aligned}$ \\
\hline 38. & $\begin{array}{c}\text { Alanine } \\
\text { transaminase } \\
(\mathrm{U} / \mathrm{L})\end{array}$ & $\begin{array}{c}0-140=\text { Low } \\
141-280=\text { Medium } \\
281-420=\text { High }\end{array}$ \\
\hline 39. & $\begin{array}{c}\text { Aspartate } \\
\text { transaminase } \\
(\mathrm{U} / \mathrm{L})\end{array}$ & $\begin{array}{c}0-184,34=\text { Low } \\
184,35-368,68= \\
\text { Medium } \\
368,69-553=\text { High }\end{array}$ \\
\hline 40. & $\begin{array}{l}\text { Gamma glutamyl } \\
\text { transferase }\end{array}$ & $\begin{array}{c}0-525=\text { Low } \\
526-1050=\text { Medium } \\
1051-1575=\text { High }\end{array}$ \\
\hline 41. & $\begin{array}{c}\text { Alkaline } \\
\text { phosphatase } \\
(\mathrm{U} / \mathrm{L})\end{array}$ & $\begin{array}{c}0-326,67=\text { Low } \\
326,68-653,34= \\
\text { Medium } \\
653,35-980=\text { High }\end{array}$ \\
\hline 42. & $\begin{array}{l}\text { Total Proteins } \\
\text { (g/dL) }\end{array}$ & $\begin{array}{c}0-34=\text { Low } \\
35-68=\text { Medium } \\
69-102=\text { High }\end{array}$ \\
\hline 43. & $\begin{array}{c}\text { Creatinine } \\
\text { (mg/dL) }\end{array}$ & $\begin{aligned} 0-2,67 & =\text { Low } \\
2,68-5,34 & =\text { Medium } \\
5,35-8 & =\text { High }\end{aligned}$ \\
\hline 44. & $\begin{array}{l}\text { Number of } \\
\text { Nodules }\end{array}$ & $\begin{array}{c}0=\text { Very Low } \\
1=\text { Low } \\
2=\text { Medium } \\
3=\text { High } \\
4=\text { Very High } \\
5=\text { Extremely High }\end{array}$ \\
\hline 45. & $\begin{array}{l}\text { Major dimension } \\
\text { of nodule }\end{array}$ & $\begin{array}{c}0-7,34=\text { Low } \\
7,35-14,68=\text { Medium } \\
14,69-22=\text { High }\end{array}$ \\
\hline 46. & $\begin{array}{l}\text { Direct Bilirubin } \\
\quad(\mathrm{mg} / \mathrm{dL})\end{array}$ & $\begin{array}{c}0-10=\text { Low } \\
11-20=\text { Medium } \\
21-30=\text { High }\end{array}$ \\
\hline 47. & Iron $(\mathrm{mcg} / \mathrm{dL})$ & $\begin{array}{c}0-81,34=\text { Low } \\
81,35-162,68= \\
\text { Medium } \\
162,69-244=\text { High }\end{array}$ \\
\hline 48. & $\begin{array}{c}\text { Oxygen } \\
\text { Saturation (\%) }\end{array}$ & $\begin{array}{c}0-42=\text { Low } \\
43-84=\text { Medium } \\
85-126=\text { High }\end{array}$ \\
\hline 49. & Ferritin $(\mathrm{ng} / \mathrm{mL})$ & $\begin{array}{c}0-743,34=\text { Low } \\
743,35-1486,68= \\
\text { Medium } \\
1486,69-2230=\text { High }\end{array}$ \\
\hline
\end{tabular}

Sumber: Penelitian (2019)

\section{Data Mining}

Pada tahap ini, penulis melakukan proses penggalian data untuk menemukan suatu pengetahuan dari sekumpulan data yang ada dengan menggunakan metode atau teknik 
tertentu yang biasa dikenal dengan istilah Data Mining. Pada penelitian ini, penulis menggunakan teknik klasifikasi untuk menggali pengetahuan yang dapat dihasilkan dari data sekunder HCC Survival Data Set dengan menerapkan algoritma Naïve Bayes sebagai algoritma untuk mengatasi masalah klasifikasi data dan menggunakan metode k-Fold CrossValidation sebagai metode untuk memvalidasi data serta membagi data secara acak menjadi $k$ subhimpunan (biasanya disebut fold) yang saling bebas sehingga masing-masing fold berisi $1 / \mathrm{k}$ bagian data yang kemudian masing-masing himpunan data berisi $(k-1)$ fold untuk data training dan 1 fold untuk data testing dengan rasio pembagian data sebesar 90:10 yaitu $90 \%$ digunakan untuk data training dan $10 \%$ sisanya digunakan untuk data testing. Jumlah fold atau subhimpunan untuk memvalidasi data yang digunakan dalam penelitian ini adalah 10-Fold Validation.

Proses data mining dilakukan dengan menggunakan software RapidMiner Studio $v 9.5$ dengan mengusung update terbaru dari segi performa maupun tampilan.

\section{Evaluation}

Pada tahap ini akan ditampilkan evaluasi terhadap kualitas dan efektifitas dari model yang telah dibangun. Proses evaluasi akan menggunakan metode Confusion Matrix serta Kurva ROC (Receiver Operating Characteristic) untuk mengetahui nilai akurasi yang dihasilkan dari model yang telah dibangun sebelumnya dengan menggunakan fitur dari software RapidMiner Studio v9.5. Tahap evaluasi dengan menggunakan software RapidMiner Studio v9.5 dilakukan secara otomatis dibelakang layar ketika mengeksekusi proses model yang telah dibangun sebelumnya. Hasil evaluasi dapat dilihat pada bagian tab Result setelah mengeksekusi model yang telah dibangun.

\section{Hasil dan Pembahasan}

Penerapan teknik klasifikasi dan penggunaan algoritma Naïve Bayes pada HCC Survival Data Set dimaksudkan untuk mengetahui dan untuk mendapatkan hasil performa yang baik pada masalah pengklasifikasian tingkat kemungkinan hidup pasien yang telah didiagnosis menderita penyakit Hepatocellular Carcinoma berdasarkan probabilitas atau kemungkinan yang dihasilkan dari beberapa gejala penyakit tersebut. Hasil performa yang optimal dapat diraih atau tidak, akan terlihat pada proses akhir eksperimen yang dilakukan. Eksperimen pada HCC Survival Data Set dilakukan dengan menggunakan teknik klasifikasi yang ditujukan untuk dapat memprediksi kemungkinan pasien dengan data gejala penyakit tertentu dapat dinyatakan 0 atau Dies (Meninggal) dan 1 atau Lives (Selamat) dengan menerapkan algortima Naïve Bayes untuk digunakan sebagai algoritma yang akan digunakan dalam teknik klasifikasi serta menggunakan metode $k$-Fold Cross-Validation untuk memvalidasi data set yang telah dipilih.

\subsection{Hasil Eksperimen Berupa Nilai Accuracy}

Dari confusion matrix yang telah dihasilkan tersebut, dapat dihasilkan nilai akurasi dari model yang sudah dibangun sebelumnya yang dapat dirumuskan dengan cara seperti dibawah ini:

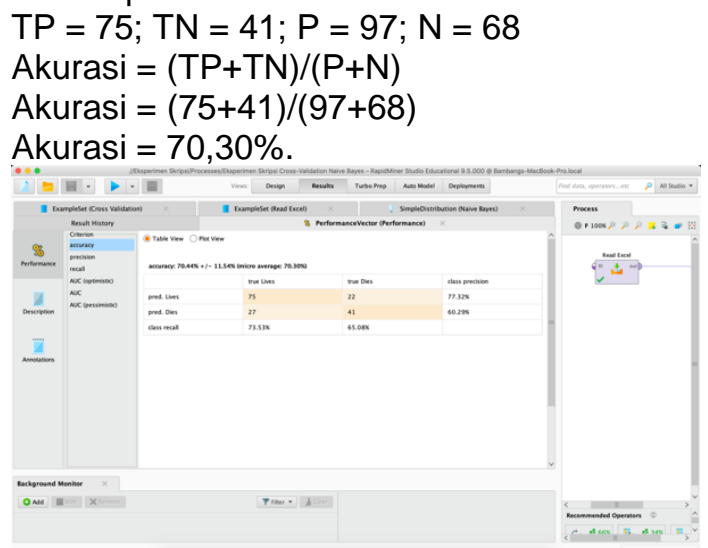

Gambar 2. Hasil Akurasi Evaluasi Model kFold Cross-Validation Sumber: Penelitian (2019)

\subsection{Hasil Eksperimen Berupa Nilai Precision}

Dari confusion matrix yang telah dihasilkan tersebut, dapat dihasilkan nilai presisi dari model yang sudah dibangun sebelumnya yang dapat dirumuskan dengan cara seperti dibawah ini:

$\mathrm{TP}=75 ; \mathrm{FP}=27$

Presisi $=\mathrm{TP} /(\mathrm{TP}+\mathrm{FP})$

Presisi $=75 /(75+27)$

Presisi $=73,53 \%$. 


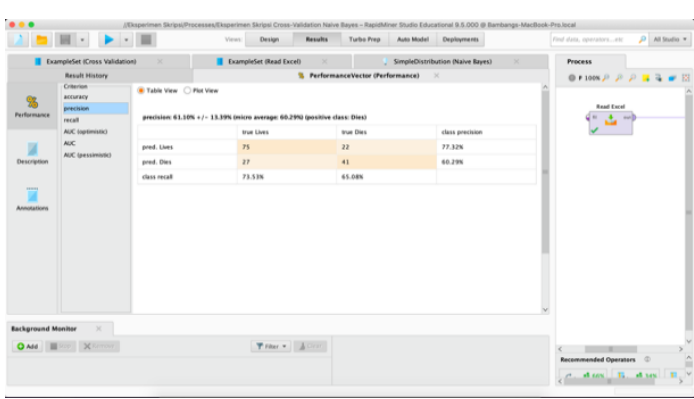

Gambar 3. Hasil Presisi Evaluasi Model kFold Cross-Validation

3.3. Hasil Eksperimen Berupa Nilai Recall Dari confusion matrix yang telah dihasilkan tersebut, dapat dihasilkan nilai recall dari model yang sudah dibangun sebelumnya yang dapat dirumuskan dengan cara seperti dibawah ini:

$\mathrm{TP}=75 ; \mathrm{P}=97$

Recall $=\mathrm{TP} / \mathrm{P}$

Recall $=75 / 97$

Recall $=77,32 \%$.

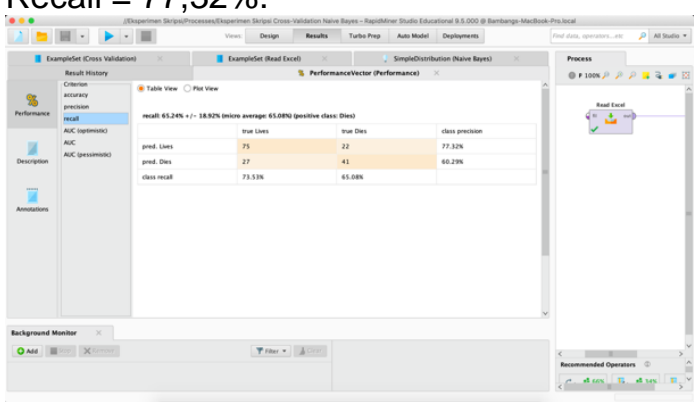

Gambar 4. Hasil Recall Evaluasi Model kFold Cross-Validation

Sumber: Penelitian (2019)

\subsection{Hasil Eksperimen Berupa Kurva ROC}

Dari visualisasi grafik Kurva ROC yang telah dihasilkan tersebut, Kurva ROC menunjukkan akurasi dan membandingkan klasifikasi secara visual dengan false positive rate (specificity) sebagai garis horizontal dan true positive rate (sensitivity) sebagai garis vertikal dengan menggambarkan tawar menawar antara sensitivitas (benefit) dan spesifisitas (cost).

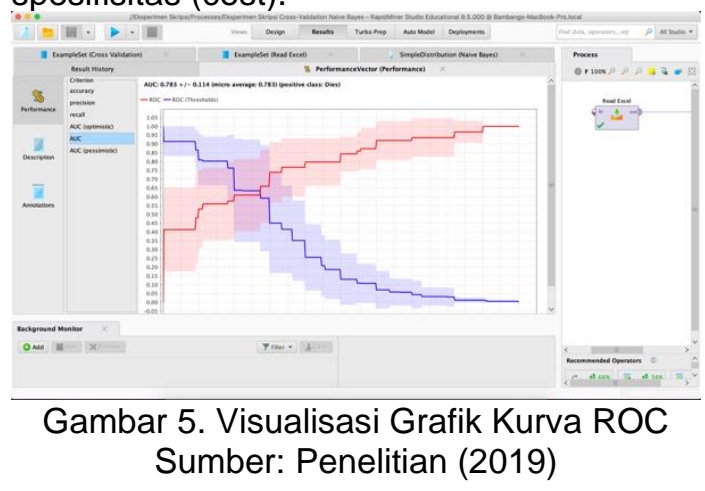

Dari grafik Kurva ROC tersebut dapat dihasilkan nilai AUC (Area Under Receiver Operating Characteristics Curve) dari model yang sudah dibangun sebelumnya dengan nilai AUC sebesar 0.783 yang termasuk didalam kategori Fair Classification atau bisa disebut juga model dengan kategori Klasifikasi Cukup.

\subsection{Perhitungan Manual Algoritma Naïve Bayes \\ Untuk mencari nilai prediksi pada data} testing dalam tahap penerapan algoritma Naïve Bayes untuk masalah klasifikasi ini, dilakukan dengan cara menghitung probabilitas prior, probabilitas bersyarat, probabilitas setiap kelas dan probabilitas posterior untuk mencari hasil dari probabilitas atau kemungkinan dari setiap masing-masing data.

Berikut adalah contoh singkat perhitungan manual proses klasifikasi dengan menggunakan algoritma Naïve Bayes pada salah satu data pasien yang diambil secara acak dari dalam data set yang digunakan.

Tabel 2. Perhitungan Manual Naïve Bayes

\begin{tabular}{|c|c|c|c|}
\hline No. & Nilai & $\begin{array}{c}\text { Probabilitas } \\
\text { Bersyarat }\end{array}$ & $\begin{array}{c}\text { Probabilitas } \\
\text { Atribut }\end{array}$ \\
\hline 1. & Male & $\begin{array}{l}\mathrm{P}(\text { Gender }=\text { Male } \\
\text { | Class Attribute } \\
=\text { Lives })=81 / 102 \\
\mathrm{P}(\text { Gender }=\text { Male } \\
\text { | Class Attribute } \\
=\text { Dies })=52 / 63\end{array}$ & $\begin{array}{l}0,794 \\
0,825\end{array}$ \\
\hline 2. & No & $\begin{array}{l}\text { P(Symptoms = } \\
\text { No | Class } \\
\text { Attribute = Lives) } \\
=41 / 102 \\
\text { P(Symptoms = } \\
\text { No | Class } \\
\text { Attribute = Dies) } \\
=12 / 63\end{array}$ & $\begin{array}{l}0,402 \\
0,190\end{array}$ \\
\hline 3. & Yes & $\begin{array}{l}\mathrm{P}(\text { Alcohol }=\text { Yes } \\
\text { Class Attribute = } \\
\text { Lives })=74 / 102 \\
\mathrm{P}(\text { Alcohol }=\text { Yes } \\
\text { Class Attribute }= \\
\text { Dies }=48 / 63\end{array}$ & $\begin{array}{l}0,725 \\
0,762\end{array}$ \\
\hline 4. & No & $\begin{array}{l}\text { P(Hepatitis B } \\
\text { Surface Antigen } \\
=\quad \text { No | Class } \\
\text { Attribute = Lives) } \\
=91 / 102 \\
\text { P(Hepatitis B } \\
\text { Surface Antigen } \\
=\quad \text { No | Class } \\
\text { Attribute = Dies) } \\
=58 / 63\end{array}$ & $\begin{array}{l}0,892 \\
0,921\end{array}$ \\
\hline
\end{tabular}




\begin{tabular}{|c|c|c|c|}
\hline 5. & No & $\begin{array}{l}\mathrm{P}(\text { Hepatitis } \mathrm{B} \text { e } \\
\text { Antigen }=\mathrm{No} \\
\text { Class Attribute = } \\
\text { Lives })=102 / 102 \\
\mathrm{P}(\text { Hepatitis } \mathrm{B} \text { e } \\
\text { Antigen }=\text { No } \\
\text { Class Attribute = } \\
\text { Dies })=62 / 63\end{array}$ & $\begin{array}{l}1 \\
0,984\end{array}$ \\
\hline
\end{tabular}

Untuk dapat menghitung probabilitas posterior dari contoh salah satu data pasien tersebut, diperlukan nilai probabilitas prior dari data set tersebut seperti perhitungan yang dilakukan dibawah ini:

Probabilitas Prior Lives $=P($ Class Attribute $=$ Lives) $=\frac{102}{165}=0,618$

Probabilitas Prior Dies $=P($ Class Attribute $=$ Dies) $=\frac{63}{165}=0,382$

Setelah itu, diperlukan perhitungan probabilitas untuk setiap jenis atribut yang dilakukan sebagai berikut:

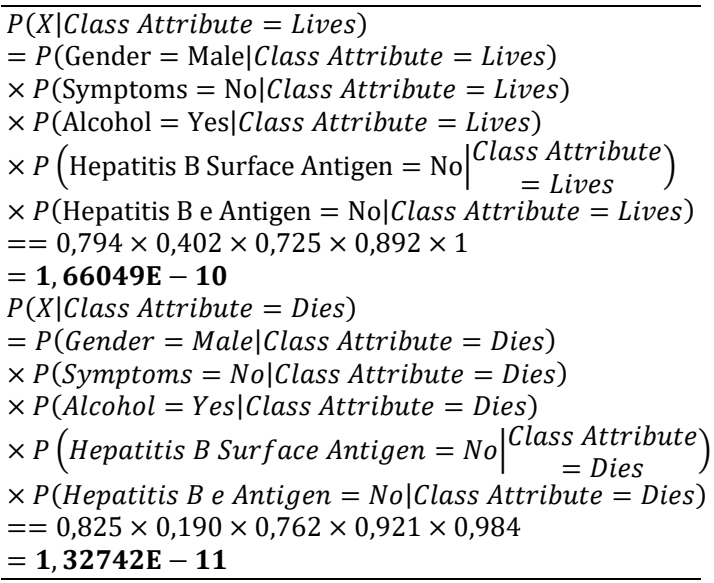

Adapun perhitungan yang dilakukan untuk mengetahui nilai probabilitas posterior dari contoh salah satu data pasien tersebut adalah sebagai berikut:

$$
\begin{aligned}
& P(X \mid \text { Class Attribute }=\text { Lives }) \\
& \quad \times P(\text { Class Attribute } \\
& =\text { Lives }) \\
& =1,66049 \mathrm{E}-10 \times 0,618=\mathbf{1}, \mathbf{0 2 6 4 8 E}-\mathbf{1 0} \\
& P(X \mid \text { Class Attribute }=\text { Dies }) \\
& \quad \times P(\text { Class Attribute }=\text { Dies }) \\
& =1,32742 \mathrm{E}-11 \times 0,382=\mathbf{5}, \mathbf{0 6 8 3 2 E}-\mathbf{1 2} \\
& \hline
\end{aligned}
$$

Berdasarkan hasil perhitungan manual tersebut, dapat diketahui bahwa probabilitas posterior $P($ Class Attribute $=$ Lives $)$ lebih besar daripada probabilitas posterior $P$ (Class
Attribute $=$ Dies). Sehingga hasil klasifikasi yang diperoleh untuk contoh salah satu data pasien tersebut bernilai Lives atau Selamat.

\section{Kesimpulan}

Pada penelitian ini dilakukan eksperimen terhadap algoritma Naïve Bayes untuk mengklasifikasi tingkat kemungkinan hidup pasien yang telah didiagnosis menderita penyakit Hepatocellular Carcinoma. Untuk mencari hasil optimal dari klasifikasi tersebut, diterapkan metode validasi untuk mengetahui performa klasifikasi berdasarkan Confusion Matrix dan Kurva ROC dengan menggunakan metode validasi $k$ - Fold Cross Validation. Kesimpulan yang didapat dari hasil penelitian ini adalah :

1. Telah diterapkan algoritma Naïve Bayes untuk mengklasifikasikan tingkat kemungkinan hidup pasien yang telah didiagnosis menderita penyakit Hepatocellular Carcinoma berdasarkan probabilitas atau kemungkinan yang dihasilkan dari beberapa gejala penyakit yang didapatkan dari catatan medis setiap individu pasien.

2. Telah diketahui hasil performa algoritma Naïve Bayes dalam mengklasifikasi penyakit berdasarkan HCC Survival Data Set yang diukur menggunakan Confussion Matrix dengan nilai yang dihasilkan berupa nilai Akurasi sebesar $70,30 \%$, Presisi sebesar $73,53 \%$ dan Recall sebesar $77,32 \%$ dengan menggunakan metode validasi 10 - Fold Cross Validation.

3. Telah diketahui hasil performa algoritma Naïve Bayes dalam mengklasifikasi penyakit berdasarkan HCC Survival Data Set yang diukur menggunakan kurva ROC (Receiver Operating Characteristic) dengan nilai yang dihasilkan berupa nilai AUC (Area Under Receiver Operating Characteristics Curve) sebesar 0.783 yang termasuk didalam kategori Fair Classification atau bisa disebut juga model dengan kategori Klasifikasi Cukup.

\section{Referensi}

Amalia, H. (2018). Perbandingan Metode Data Mining SVM dan NN Untuk Klasifikasi Penyakit Ginjal Kronis. Jurnal PILAR Nusa Mandiri, 1-6.

Kemenkes. (2019). Hari Kanker Sedunia 2019.

https://www.kemkes.go.id/article/view/1 9020100003/hari-kanker-sedunia- 
2019.html

Nugraha, F. S., Shidiq, M. J., \& Rahayu, S. (2019). Analisis Algoritma Klasifikasi Neural Network Untuk Diagnosis Penyakit Kanker Payudara . Jurnal PILAR Nusa Mandiri, 149-156.

Ramdhani, Y. (2015). Komparasi Algoritma LDA Dan Naïve Bayes Dengan Optimasi Fitur Untuk Klasifikasi Citra Tunggal Pap Smear. Jurnal Informatika, 2(2).

Ramdhani, Y., Susanti, S., Adiwisastra, M. F., \& Topiq, S. (2018). Penerapan Algoritma Neural Network Untuk Klasifikasi Kardiotokografi. Jurnal Informatika, 5(1), 43-49. https://doi.org/10.31311/ji.v5i1.2832

Saleh, A. (2015). Implementasi Metode Klasifikasi Naïve Bayes Dalam Memprediksi Besarnya Penggunaan Listrik Rumah Tangga. Citec Journal, 207-217.

Santosa, B., \& Umam, A. (2018). Data Mining dan Big Data Analytics Teori dan Implementasi Menggunakan Python dan Apache Spark. Yogyakarta: Penebar Media Pustaka.

Sugiarti, M. (2015). Pengaruh Khemoterapi Terhadap Jumlah Trombosit Pasien Penderita Kanker di RS Abdul Moeloek Provinsi Lampung. Jurnal Analis Kesehatan, 450-455.

Susanti, S. (2019). Klasifikasi Kemampuan Perawatan Diri Anak dengan Disabilitas Menggunakan SMOTE Berbasis Neural Network. Jurnal Informatika, 6(2), 175-184.

Yulianto, T., Kuzairi, \& Hasanah, R. (2016). Mplementasi Metode Lagrange
Untuk Optimasi Penyakit Kanker Hati. Unisda Journal of Mathematics and Computer Science, 62-68. 